\title{
Hubungan Pola Asuh Demokratis Orang Tua terhadap Kedisiplinan Ibadah Siswa Kelas XI IPS 4 di SMA N 1 Luhak Nan Duo
}

\author{
Rahmah Hayati ${ }^{1}$, Murniyetti ${ }^{2}$ \\ rahmahhayati68@gmail.com ${ }^{1}$, murniyetti21@gmail.com ${ }^{2}$ \\ Universitas Negeri Padang1 $1^{1,2}$
}

\begin{tabular}{|c|c|}
\hline ART & ABSTRACT \\
\hline Article history: & \multirow{12}{*}{$\begin{array}{l}\text { Penelitian ini dilatarbelakangi oleh kurangnya } \\
\text { kedisiplinan ibadah siswa kelas XI IPS } 4 \text { dalam } \\
\text { melaksanakan ibadah shalat. Penelitian ini bertujuan } \\
\text { untuk mendeskripsikan pola asuh demokratis orang } \\
\text { tua dan kedisiplinan ibadah siswa, serta menguji } \\
\text { hubungan pola asuh demokratis orang tua terhadap } \\
\text { kedisiplinan ibadah siswa kelas XI IPS } 4 \text { di SMA N } 1 \\
\text { Luhak Nan Duo. Penelitian ini menggunakan } \\
\text { pedekatan kuantitatif dengan jenis deskriptif } \\
\text { korelasional. Pengambilan sampel dilakukan dengan } \\
\text { teknik purposive sampling. Data dianalisis } \\
\text { menggunakan statistic deskriptif dengan teknik } \\
\text { presentase. Untuk menguji normalitas, linearitas dan } \\
\text { hubungan antarvariabel menggunakan analisis } \\
\text { statistic produk momen pearson dibantu program } \\
\text { SPSS 20. Berdasarkan hasil penelitian dapat } \\
\text { disimpulkan bahwa secara keseluruhan gambaran pola } \\
\text { asuh demokratis orang tua dan kedisiplinan ibadah } \\
\text { siswa berada pada kategori sedang. Hasil perhitungan } \\
\text { analisis korelasional product moment antara pola asuh } \\
\text { demokratis orang tua terhadap kedisiplinan ibadah } \\
\text { siswa di SMA N } 1 \text { Luhak Nan Duo diperoleh sebesar } \\
\text { 0,285. Hal ini menunjukkan tidak terdapatnya } \\
\text { hubungan antara pola asuh demokratis orang tua } \\
\text { dengan kedisiplinan ibadah siswa. }\end{array}$} \\
\hline tus 2021 & \\
\hline Revised 24 Agustus 2021 & \\
\hline Acc & \\
\hline & \\
\hline & \\
\hline Demokratis, & \\
\hline Orang Tua, Kedisiplinan, & \\
\hline Ibadah & \\
\hline $\begin{array}{l}\text { Clonflict of Interest: } \\
\text { None }\end{array}$ & \\
\hline Funding: & \\
\hline Non & \\
\hline
\end{tabular}

Corresponding Author: Rahmah Hayati, Department Islamic Education, Faculty of Social Science, Universitas Negeri Padang, Indonesia, Email: rahmahhayati68@gmail.com Phone: +62822-8337-5532

(c) (i) Copyright (C2021, Author(s)

\section{Pendahuluan}

Disiplin adalah proses bimbingan yang bertujuan untuk menanamkan tingkah laku, kebiasaan-kebiasaan tertentu atau membentuk manusia dengan ciriciri tertentu (Mini, 2011: 7). Kedisiplinan membangun kebiasaan baik seseorang, 
Rahmah Hayati dan Murniyetti: Hubungan Pola Asuh Demokratis Orang Tua terhadap...

meningkatkan kemampuannya dalam bertahan, serta melindungi orang dari godaan yang membingungkan dan pola hidup yang membahayakan atau tidak seimbang. Orang yang mampu mengendalikan emosi atau keinginan hatinya secara bijak dapat lebih serius pada tujuan yang akan dicapainya (Garmo, 2011: 46).

Kedisiplinan dalam beribadah perlu ditanamkan sejak dini, terutama pada masa remaja yaitu ketika anak menginjak bangku Sekolah Menengah Atas (SMA), Madrasah Aliyah (MA) atau sederajat. Karena akan menentukan kehidupan seseorang dalam kehidupannya kelak ketika dewasa. Dengan menanamkan disiplin beribadah pada anak maka diharapkan adanya kesadaran beribadah dalam kehidupannya sehari-hari disamping dukungan dari lingkungan yang baik.

Menurut Agus Wibowo dalam Wati (2019: 8) salah satu faktor yang secara signifikan turut membentuk disiplin anak adalah pola asuh atau parenting style. Pola asuh orang tua juga merupakan salah satu faktor pengembangan kedisiplinan anak, orang tua merupakan model bagi anak dalam pembentukan disiplin dirumah sehingga orang tua juga harus disiplin dalam menentukan peraturan yang akan diterapkan di rumah.

Muslima (2015: 87) menjelaskan bahwa pola asuh orangtua adalah keseluruhan interaksi antara orangtua dengan anak guna mendorong anaknya dengan mengubah sikap, pengetahuan serta nilai-nilai yang dianggap paling tepat oleh orangtua agar anak dapat mandiri, tumbuh dan berkembang secara sehat dan optimal. Iqbal (2018: 64) mengemukakan bahwa orang tua menjadi teladan dan panutan bagi anak sehingga pendidikan sejak dini menjadi perhatian penting bagi orang tua. Peran orang tua sangat penting dalam pembentukan karakter anak. Pola asuh anak menjadi sangat penting, terutama dalam hal penerapan nilai-nilai agama dan akhlak sehingga anak memiliki dasar pendidikan yang baik untuk masa depannya.

Selanjutnya Stewart \& Koch dalam Tridhonanto \& Agency (2014: 12-14) menyatakan bahwa pola asuh orangtua terdiri dari tiga jenis, yaitu pola asuh otoriter (Authoritarian Parenting), pola asuh permisif (Permissive Parenting) dan pola asuh demokrasi (Authoritative Parenting). Ketiga jenis pola asuh tersebut memiliki dampak yang berbeda-beda bagi perkembangan anak. Perbedaan pola asuh yang diterapkan orang tua kepada anak berpengaruh terhadap perbedaan tingkah laku atau karakter yang dimiliki anak. Dari ketiga jenis pola asuh orang tua, bentuk pola asuh demokratis adalah pola asuh paling baik diterapkan kepada anak. Karena dalam pola asuh demokratis, orang tua memberikan kebebasan kepada anak untuk memilih dan melakukan suatu tindakan dengan memperhatikan aturan dan norma yang berlaku, serta pendekatannya kepada anak bersifat hangat.

Rakhmawati (2015: 6) menjelaskan bahwa pola asuh demokratis adalah pola asuh yang memberikan kebebasan serta bimbingan kepada anak. Anak dapat berkembang secara wajar dan mampu berhubungan secara harmonis dengan orang tuanya. Anak akan bersifat terbuka, bijaksana karena adanya komunikasi dua arah. Sedangkan orang tua bersikap obyektif, perhatian dan memberikan dorongan positif kepada anaknya.

Berdasarkan observasi penulis di SMA N 1 Luhak Nan Duo, KM. 08 Simpang Empat-Manggopoh, Kecamatan Luhak Nan Duo, Kabupaten Pasaman Barat, tempat penulis melaksanakan Praktek Lapangan Kependidikan (PLK) periode semester Juli-Desember 2020 ditemukan kurangnya kedisiplinan ibadah siswa kelas XI IPS 4 seperti siswa suka menunda sholat, menghabiskan waktu untuk berkumpul 
bersama temannya sehingga terlambat melaksanakan sholat bahkan meninggalkan sholat, siswa malas melaksanakan sholat lima waktu, jarang melaksanakan sholat berjamaah di masjid, sering datang terlambat ke sekolah dan tidak memasukkan baju seragam.

Berdasarkan hasil wawancara pada tanggal 08 Februari 2021 dengan guru Bimbingan dan Konseling (BK), guru yang mengajar di kelas XI dan mahasiswa Praktek Lapangan (PL) ditemukan bahwa dari keseluruhan siswa kelas XI, siswa kelas XI IPS 4 memiliki kedisiplinan yang kurang baik. Siswa malas dan tidak bersemangat dalam belajar, tidak membuat tugas jika belajar secara daring, tidak merespon pertanyaan dari guru, dan siswa sering terlambat dengan banyak alasan. Hal ini didukung oleh informasi yang diberikan oleh guru Bimbingan dan Konseling (BK), ternyata siswa kelas XI IPS 4 adalah siswa yang sering bermasalah seperti sering absen dan jarang membuat tugas sehingga sering dipanggil orang tuanya oleh guru Bimbingan dan Konseling (BK).

Salah satu pembentuk karakter anak adalah perilaku orang tua, anak mulai belajar dan meniru apa yang dilihatnya. Pengasuhan keluarga sangat penting bagi perkembangan anak. Dengan demikian anak harus diasuh dengan hal-hal yang baik, yaitu mulai dengan mengenalkan agama, mengajarkan disiplin, berperilaku jujur, suka menolong, dan hal-hal yang positif harus diajarkan orang tua kepada anak sedini mungkin, agar tertanam dalam jiwa anak (Rakhmawati, 2015: 3).

Penelitian ini bertujuan untuk mendeskripsikan pola asuh demokratis orang tua dan kedisiplinan ibadah siswa kelas XI IPS 4 di SMA N 1 Luhak Nan Duo serta menguji hubungan pola asuh demokratis orang tua dengan kedisiplinan ibadah siswa kelas XI IPS 4 di SMA N 1 Luhak Nan Duo.

Perbedaan penelitian ini dengan penelitian sebelumnya yaitu penelitian Salis Ulfa Fariha (2016) dengan judul "Hubungan Pola Asuh Demokratis dengan Kedisiplinan Siswa Kelas V SD Negeri Kecamatan Bangsri Kabupaten Jepara" memiliki kaitan dengan penelitian ini yaitu kaitan persamaannya terletak pada variabel (X) Pola Asuh Demokratis dan memiliki perbedaan variabel yang diteliti yaitu variabel (Y) kedisiplinan.

\section{Tinjauan Pustaka}

\section{A. Pola Asuh Demokratis Orang Tua}

\section{1) Pola Asuh Demokratis Orang Tua}

Siswanto (2020: 46) menjelaskan pola asuh demokratis adalah pola asuh yang mementingkan kepentingan anak, akan tetapi tetap mengarahkan anak apabila dalam keadaan membahayakan. Orang tua dengan tipe ini akan bersikap realistis terhadap kemampuan anak, tidak berharap berlebihan yang melampaui kemampuan anak dan tidak pula merendahkan dengan menganggap remeh kemampuan anak. Mereka memberikan kesempatan kepada anak untuk memilih dan melakukan suatu tindakan dan pendekatannya pun bersifat hangat.

Menurut Ulfah (2020: 97-98) pola asuh demokratis adalah sikap dan cara orang tua dalam mempersiapkan anak agar bisa mengambil keputusan sendiri sehingga anak mengalami perubahan dari keadaan bergantung kepada orang tua menjadi mandiri dan bertanggung jawab. Selanjutnya, Widyarini (2013: 11) menjelaskan orang tua yang memiliki pola asuh demokratis berusaha 
Rahmah Hayati dan Murniyetti: Hubungan Pola Asuh Demokratis Orang Tua terhadap...

mengarahkan anaknya secara rasional, berorientasi pada masalah yang dihadapi, menghargai komunikasi yang saling memberi dan menerima, menjelaskan alasan rasional yang mendasari tiap permintaan atau disiplin tetapi juga menggunakan kekuasaan bila perlu, mengharapkan anak untuk mandiri dan mengarahkan diri sendiri, saling menghargai antara anak dan orangtua, memperkuat standar-standar perilaku. Orangtua tidak mengambil posisi mutlak, tetapi juga tidak mendasarkan pada kebutuhan anak semata.

\section{2) Ciri-Ciri Pola Asuh Demokratis Orang Tua}

Siswanto (2020, 45-46) menjelaskan ciri-ciri pola asuh demokratis yaitu Menentukan peraturan dan disiplin dengan memperhatikan dan mempertimbangkan alasan-alasan yang dapat diterima, dipahami dan dimengerti oleh anak, 2) Memberikan pengarahan tentang perbuatan baik yang perlu dipertahankan dan yang tidak baik agar ditinggalkan, 3) Memberikan bimbingan dengan penuh pengertian, 4) Dapat menciptakan keharmonisan dalam keluarga, dan 5) Dapat menciptakan suasana komunikatif antara orang tua dan anak serta sesama keluarga.

\section{3) Aspek-Aspek Pola Asuh Demokratis Orang Tua}

Adapun aspek-aspek pola asuh demokratis menurut Idris \& Jamal (1992: 87) adalah sebagai berikut. Orang tua menentukan peraturan dan disiplin dengan memperhatikan dan memperimbangkan alasan-alasan yang dapat diterima, dipahami dan dimengerti oleh anak. Orang tua memberikan pengarahan tentang perbuatan baik yang perlu dipertahankan dan yang tidak baik agar ditinggalkan Orang tua memberikan bimbingan dengan penuh pengertian, orang tua menciptakan keharmonisan dalam keluarga, dan orang tua dapat menciptakan suasana komunikatif antara orang tua dan anak serta sesama keluarga.

\section{4) Faktor-Faktor yang Mempengaruhi Pola Asuh Orang Tua}

Ermi (2017: 66) menjelaskan perlakuan orang tua terhadap anak-anaknya sangat dipengaruhi oleh faktor-faktor sebagai berikut.

a. Pengalaman masa lalu

Perlakuan orang tua terhadap anak-anaknya mencerminkan perlakuan yang mereka terima sewaktu kecil. Bila perlakuan yang mereka terima keras dan kejam, maka perlakuan terhadap anak-anaknya juga seperti itu.

b. Kepribadian orang tua

Kepribadian orang tua dapat mempengaruhi cara mengasuhnya. Orangtua yang berkepribadian tertutup dan konservatif cenderung memperlakukan anaknya dengan ketat dan otoriter.

c. Nilai-nilai yang dianut orang tua

Ada sebagian orang tua yang menganut faham aqualitarian yaitu kedudukan anak sama dengan kedudukan orang tua, ini di negara Barat. Sedangkan di negara Timur nampaknya orang tua masih cenderung menghargai keputusan anak.

\section{B. Kedisiplinan Ibadah}

\section{1) Pengertian Kedisiplinan Ibadah}

Yasyakur (2016: 1199) menjelaskan disiplin beribadah adalah melakukan ketertiban, keteraturan, ketaatan dalam beribadah serta menyempurnakan ibadah dengan melaksanakan segala peraturan yang berlaku. Hasan (2012: 138) mengemukakan bahwa disiplin ibadah adalah 
perasaan taat dan patuh terhadap perbuatan atau pernyataan bakti terhadap Allah SWT yang didasari oleh peraturan agama. Secara khusus, disiplin ibadah dibagi atas tanggung jawab pelaksanaan ibadah, kepatuhan pada tata cara ibadah dan ketepatan waktu ibadah.

Dari pengertian di atas dapat disimpulkan bahwa disiplin ibadah adalah ketaatan dan kepatuhan dalam beribadah kepada Allah SWT yang didasari aturan-aturan agama.

Kedisiplinan ibadah dalam penelitian ini diutamakan dalam menjalankan ibadah shalat, membaca Al-Qur'an, taat terhadap peraturan sekolah dan berbuat baik kepada sesama manusia.

\section{Unsur-Unsur Disiplin}

Unsur-unsur penting disiplin menurut Hurlock dalam (Rochimi, 2018: 236) yaitu: 1) Peraturan, diterapkan untuk membekali anak dan membantu mengekang perilaku yang tidak diinginkan yang dapat diterima anak, 2) Penghargaan, digunakan untuk menumbuhkan disiplin anak yaitu mempunyai nilai mendidik, sebagai motivasi, dan memperkuat perilaku yang disetujui secara sosial. Penghargaan tidak perlu berbentuk materi, tetapi dapat berupa kata pujian, senyuman atau tepukan di punggung, 3) Hukuman, diberikan karena seseorang melakukan kesalahan. Tujuannya adalah untuk menghentikan perilaku yang salah agar anak dapat berperilaku sesuai dengan standar yang telap ditetapkan untuk selanjutnya, dan 4) Konsistensi, ada dalam peraturan dijadikan sebagai pedoman, serta hukuman dan penghargaan. Konsistensi memiliki peranan penting yaitu nilai mendidik yang besar, nilai motivasi yang kuat, serta mempertinggi penghargaan terhadap peraturan dan orang yang berkuasa.

\section{2) Faktor yang Mempengaruhi Kedisiplinan Ibadah}

Muslihun, dkk $(2018,264)$ memaparkan faktor yang mempengaruhi kedisiplinan ibadah yaitu.
a) Kesadaran pada diri sendiri.
b) Keteladanan kedua orang tua.
c) Keteladanan para guru.
d) Kekuatan kehendak pada diri sendiri.
e) Pengaruh positif dan negatif teman.

\section{Metodologi}

Penelitian ini menggunakan pendekatan kuantitatif dengan jenis deskriptif korelasional. Populasi penelitian adalah siswa SMA N 1 Luhak Nan Duo yang berjumlah 29. Peneliti mengambil seluruh populasi menjadi anggota sampel yaitu berjumlah 26 orang siswa dikarenakan 3 orang siswa beragama nonmuslim Pengambilan sampel dilakukan dengan teknik purposive sampling. Data dikumpulkan dengan angket menggunakan skala likert. Data dianalisis dengan menggunakan rumus product moment correlation.

\section{Hasil dan Pembahasan}

\section{Deskripsi Data Pola Asuh Demokratis Orang Tua}

Berdasarkan hasil penelitian ditemukan Pola Asuh Demokratis Orang Tua siswa kelas XI IPS 4 di SMA N 1 Luhak Nan Duo, seperti tabel berikut. 
Rahmah Hayati dan Murniyetti: Hubungan Pola Asuh Demokratis Orang Tua terhadap...

Tabel 1. Distribusi Frekuensi dan Persentase Pola Asuh Demokratis Orang Tua $(n=26)$

\begin{tabular}{cccc}
\hline Kategori & Interval & Frekuensi & $\%$ \\
\hline Sangat Tinggi & $\geq 191$ & 2 & 7,6923 \\
Tinggi & 173 s/d 191 & 6 & 23,077 \\
Sedang & 154 s/d 173 & 10 & 38,462 \\
Rendah & 135 s/d 154 & 7 & 26,923 \\
Sangat & $<135$ & 1 & 3,8462 \\
Rendah & & & \\
\multicolumn{2}{c}{ Total } & 26 & 100 \\
\hline
\end{tabular}

Berdasarkan tabel di atas, diketahui pola asuh demokratis orang tua $38,46 \%$ berada pada kategori sedang, 23,07\% berada pada kategori tinggi, $26,92 \%$ berada pada kategori rendah, $7,69 \%$ berada pada kategori sangat tinggi dan 3,84\% berada pada kategori sangat rendah. Berdasarkan hasil pengolahan data dapat diketahui pola asuh demokratis orang tua berada pada kategori sedang dengan jumlah 10 dan presentase sebesar 38,462\%.

\section{Deskripsi Data Kedisiplinan Ibadah Siswa}

Tabel 2. Distribusi Frekuensi dan Persentase Kedisiplinan Ibadah Siswa $(n=26)$

\begin{tabular}{cccc}
\hline Kategori & Interval & Frekuensi & $\%$ \\
\hline Sangat Tinggi & $\geq 107$ & 1 & 3,8462 \\
Tinggi & 97 s/d 107 & 8 & 30,769 \\
Sedang & 86 s/d 97 & 8 & 30,769 \\
Rendah & 75 s/d 86 & 8 & 30,769 \\
Sangat & $<75$ & 1 & 3,8462 \\
Rendah & & & \\
\multicolumn{2}{c}{ Total } & 26 & 100 \\
\hline
\end{tabular}

Berdasarkan Tabel 2 di atas, ditemukan bahwa kedisiplinan ibadah siswa yaitu 30,76\% berada pada kategori sedang, 30,76\% berada pada kategori tinggi, 30,76\% berada pada kategori rendah, 3,84\% berada pada kategori sangat tinggi dan 3,84\% berada pada kategori sangat rendah. Berdasarkan hasil pengolahan data dapat diketahui kedisiplinan ibadah siswa berada pada kategori sedang dengan jumlah 8 dan presentase sebesar 30,76.

Hubungan Pola Asuh Demokratis Orang Tua terhadap Kedisiplinan Ibadah Siswa Kelas XI IPS 4 di SMA N 1 Luhak Nan Duo

Berdasarkan hasil pengujian hipotesis penelitian terlihat pada tabel berikut.

Tabel 3. Korelasi Pola Asuh Demokratis Orang Tua terhadap Kedisiplinan Ibadah Siswa Kelas XI IPS 4 di SMA N 1 Luhak Nan Duo

Correlations

Pola Asuh Kedisiplinan 


\begin{tabular}{|c|c|c|c|}
\hline & & $\begin{array}{c}\text { Demokratis } \\
\text { Orang Tua }\end{array}$ & Ibadah \\
\hline \multirow{3}{*}{$\begin{array}{l}\text { Pola Asuh } \\
\text { Demokratis } \\
\text { Orang Tua }\end{array}$} & Pearson & 1 & .285 \\
\hline & Correlation & & \\
\hline & Sig. (2-tailed) & & .158 \\
\hline \multirow{4}{*}{$\begin{array}{l}\text { Kedisiplinan } \\
\text { Ibadah }\end{array}$} & $\mathrm{N}$ & 26 & 26 \\
\hline & $\begin{array}{c}\text { Pearson } \\
\text { Correlation }\end{array}$ & .285 & 1 \\
\hline & Sig. (2-tailed) & .158 & \\
\hline & $\mathrm{N}$ & 26 & 26 \\
\hline
\end{tabular}

Berdasarkan hasil perhitungan menunjukkan koefisien korelasi dari pola asuh demokratis orang tua terhadap kedisiplinan ibadah siswa adalah sebesar 0,285 . Hal ini menunjukkan tidak terdapat hubungan antara pola asuh demokratis orang tua dengan kedisiplinan ibadah siswa. Berdasarkan hasil signifikansi dari tabel 3 maka diketahui antara variabel pola asuh demokratis orang tua dengan variabel kedisiplinan ibadah memiliki nilai signifikansi 0,158 $>0,05$ yang berarti tidak terdapat korelasi. Sehingga dapat disimpulkan bahwa pola asuh demokratis orang tua tidak mempengaruhi kedisiplinan ibadah siswa kelas XI IPS 4 di SMA N 1 Luhak Nan Duo.

Berdasarkan hasil pengujian hipotesis di atas, dapat disimpulkan hasil penelitian dalam bentuk gambar hubungan pola asuh demokratis orang tua terhadap kedisiplinan ibadah siswa kelas XI IPS 4 di SMA N 1 Luhak Nan Duo seperti gambar 1 berikut.

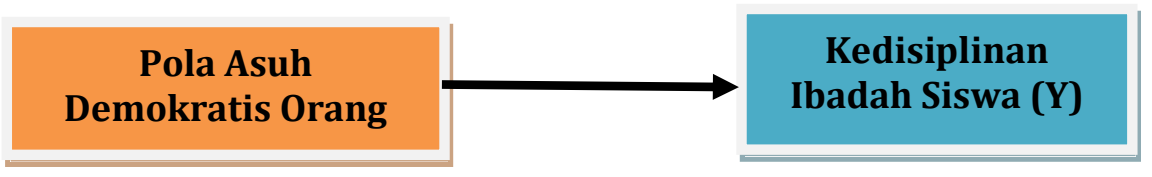

\section{Gambar 1. Hubungan Pola Asuh Demokratis Orang Tua (X) terhadap Kedisiplinan Ibadah Siswa (Y) Kelas XI IPS 4 di SMA N 1 Luhak Nan Duo}

\section{A. Pembahasan}

Berdasarkan hasil penelitian ditemukan nilai koefisien hubungan pola asuh demokratis orang tua terhadap kedisiplinan ibadah adalah sebesar 0,285. Hal ini menunjukkan hubungan antara variabel pola asuh demokratis orang tua terhadap kedisiplinan ibadah siswa kelas XI IPS 4 di SMA N 1 Luhak Nan Duo dalam kategori rendah karena berada padaBerdasakan hasil penelitian yang telah dilakukan menunjukkan pada umumnya pola asuh demokratis orang tua berada pada kategori sedang. Hal ini diketahui dari temuan dalam penelitian sampel yang berjumlah 26 orang siswa ditemukan sebagian besar pola asuh demokratis orang tua berada pada kategori sedang dengan jumlah 10 dan presentase sebesar $38,462 \%$ sedangkan skor terendah sebesar 1 dengan persentase 3,84\% yang berada pada kategori sangat rendah.

Secara keseluruhan persentase sebesar 74,30\%, dan standar deviasi $18,69 \%$. Berdasarkan hasil penelitian, sebagian besar pola asuh demokratis 
Rahmah Hayati dan Murniyetti: Hubungan Pola Asuh Demokratis Orang Tua terhadap...

orang tua siswa kelas XI IPS 4 di SMA N 1 Luhak Nan Duo berada pada kategori sedang. Artinya sebagian besar siswa sudah memiliki pola asuh demokratis dengan baik. Siswanto (2020: 46) menjelaskan pola asuh demokratis adalah pola asuh yang mementingkan kepentingan anak, akan tetapi tetap mengarahkan anak apabila dalam keadaan membahayakan. Orang tua dengan tipe ini akan bersikap realistis terhadap kemampuan anak, tidak berharap berlebihan yang melampaui kemampuan anak dan tidak pula merendahkan dengan menganggap remeh kemampuan anak. Mereka memberikan kesempatan kepada anak untuk memilih dan melakukan suatu tindakan dan pendekatannya pun bersifat hangat.

\section{Gambaran Kedisiplinan Ibadah Siswa}

Hasil analisis data penelitian mengenai kedisiplinan ibadah siswa kelas XI IPS 4 di SMA N 1 Luhak Nan Duo rata-rata secara keseluruhan berada dalam kategori sedang. Berdasarkan pencapaian masing-masing indikator diketahui ke-empat indikator termasuk dalam kategori sedang, yaitu: 1) Peraturan, 2) Penghargaan, 3) Hukuman, dan 3) Konsistensi.

Berdasakan hasil penelitian yang telah dilakukan menunjukkan pada umumnya kedisiplinan ibadah siswa kelas XI IPS 4 di SMA N 1 Luhak Nan Duo berada pada kategori sedang. Hal ini diketahui dari temuan dalam penelitian sampel yang berjumlah 26 orang siswa ditemukan sebagian besar kedisiplinan ibadah berada pada skor tertinggi sebesar 8 dengan persentase 30,77\% sedangkan skor terendah sebesar 1 dengan persentase 3,84\% yang berada pada kategori sangat rendah. Secara keseluruhan persentase sebesar 41,42\%, dan standar deviasi 10,89.

Berdasarkan hasil penelitian diperoleh kedisiplinan ibadah siswa berada pada kategori sedang sebesar 30,77\% dengan jumlah 8 siswa, selain itu berada pada kategori tinggi sebesar 30,77\% dengan jumlah 8 siswa, berada pada kategori rendah sebesar 30,77\% dengan jumlah 8 , berada pada kategori sangat tinggi sebesar 3,84\% dengan jumlah 1 siswa dan berada pada kategori sangat rendah sebesar 3,84\% dengan jumlah 1 siswa. Dengan begitu artinya sebagian besar siswa memiliki kedisipinan ibadah yang baik. Kedisiplinan membangun kebiasaan baik seseorang, meningkatkan kemampuannya dalam bertahan, serta melindungi orang dari godaan yang membingungkan dan pola hidup yang membahayakan atau tidak seimbang. (Garmo, 2011: 46).

\section{Hubungan Pola Asuh Demokratis Orang Tua terhadap Kedisiplinan Ibadah Siswa Kelas XI IPS 4 di SMA N 1 Luhak Nan Duo}

Menurut Agus Wibowo dalam Wati (2019: 8) salah satu faktor yang secara signifikan turut membentuk disiplin anak adalah pola asuh atau parenting style. Pola asuh orang tua juga merupakan salah satu faktor pengembangan kedisiplinan anak, orang tua merupakan model bagi anak dalam pembentukan disiplin di rumah sehingga orang tua juga harus disiplin dalam menentukan peraturan yang akan diterapkan di rumah.

Rakhmawati (2015: 6) menjelaskan bahwa pola asuh demokratis adalah pola asuh yang memberikan kebebasan serta bimbingan kepada anak. Anak dapat berkembang secara wajar dan mampu berhubungan secara harmonis dengan orang tuanya. Anak akan bersifat terbuka, bijaksana karena 
adanya komunikasi dua arah. Sedangkan orang tua bersikap obyektif, perhatian dan memberikan dorongan positif kepada anaknya.

Hasil perhitungan analisis korelasional product moment antara pola asuh demokratis orang tua terhadap kedisiplinan ibadah siswa di SMA N 1 Luhak Nan Duo adalah sebesar 0,285. Hal ini menunjukkan tidak terdapat hubungan antara pola asuh demokratis orang tua dengan kedisiplinan ibadah siswa.

Sementara nilai signifikansi menunjukkan nilai sebesar 0,158 $>0,05$. Sehingga hipotesis alternatif $(\mathrm{Ha})$ yang menyatakan bahwa terdapat hubungan yang signifikan antara pola asuh demokratis orang tua terhadap kedisiplinan ibadah siswa kelas XI IPS 4 di SMA N 1 Luhak Nan Duo ditolak, yang berarti bahwa tidak terdapat hubungan yang signifikan antara pola asuh demokratis orang tua terhadap kedisiplinan ibadah siswa kelas XI IPS 4 di SMA N 1 Luhak Nan Duo.

\section{Simpulan}

Berdasarkan temuan dan pembahasan hasil penelitian, maka dapat dikemukakan kesimpulan, yaitu sebagai berikut:

1. Secara keseluruhan gambaran pola asuh demokratis orang tua berada pada kategori sedang. Artinya secara keseluruhan siswa sudah berada dalam pola asuh demokratis orang tua yang baik.

2. Secara keseluruhan gambaran kedisiplinan ibadah berada pada kategori sedang. Artinya secara keseluruhan ada siswa yang kurang disiplin dalam beribadah.

3. Hasil perhitungan analisis korelasional product moment antara pola asuh demokratis orang tua terhadap kedisiplinan ibadah siswa di SMA N 1 Luhak Nan Duo diperoleh sebesar 0,285. Hal ini menunjukkan tidak terdapat hubungan antara pola asuh demokratis orang tua dengan kedisiplinan ibadah siswa.

4. Nilai signifikansi menunjukkan nilai sebesar $0,158>0,05$. Sehingga hipotesis alternatif (Ha) yang menyatakan bahwa terdapat hubungan yang signifikan antara pola asuh demokratis orang tua terhadap kedisiplinan ibadah siswa kelas XI IPS 4 di SMA N 1 Luhak Nan Duo ditolak, yang berarti bahwa tidak terdapat hubungan yang signifikan antara pola asuh demokratis orang tua terhadap kedisiplinan ibadah siswa kelas XI IPS 4 di SMA N 1 Luhak Nan Duo.

\section{Referensi}

Ermi, E. Upaya Meningkatkan Prestasi Belajar IPA dengan Pendekatan Metakognitif Kelas VI di SDN 153 Pekan Baru. Indragiri Journal. 1(2).

Garmo, J. 2013. Pengembangan Karakter untuk Anak: Panduan Pendidik. Jakarta Pusat: Kensain Blanc.

Idris, Z. \& Jamal, L. 1992. Pengantar Pendidikan I. Jakarta: Gramedia Widiasarana Indonesia.

Iqbal, M. 2018. Psikologi Pernikahan. Gema Insani: Depok.

Mini, R. 2011. Disiplin pada Anak Usia Dini. Direktorat Jenderal Pendidikan Anak Usia Dini Nonformal dan Informal Kementrian Pendidikan Nasional.

Muslihun, dkk. 2018. Peran Guru Pendidikan Agama Islam (PAI) dan Budi Pekerti dalam Meningkatkan Kedisiplinan Ibadah Shalat Berjamaah Siswa di SMP IT 
Rahmah Hayati dan Murniyetti: Hubungan Pola Asuh Demokratis Orang Tua terhadap...

Al-Hidayah Nogor Tahun Ajaran 2018-2019. Prodi Pendidikan Agama Islam STAI Al-Hidayah Bogor.

Muslima. 2015. Pola Asuh Finansial terhadap Kecerdasan Finansial Anak. International Journal of Child and Gender Studies. 1 (1).

Rakhmawati, I. 2015. Peran Keluarga dalam Pengasuhan Anak. Jurnal Bimbingan Konseling Islam. 6 (1).

Rochimi, I. F. \& Suismanto. 2018. Upaya Guru Menanamkan Nilai-Nilai Kedisiplinan pada Anak Usia Dini. Jurnal Ilmiah Tumbuh Kembang Anak Usia Dini. 4(3).

Salis Ulfa Fariha 2016. Hubungan Pola Asuh Demokratis dengan Kedisiplinan Siswa Kelas V SD Negeri Kecamatan Bangsri Kabupaten Jepara. Skripsi. Semarang: Jurusan Pendidikan Guru Sekolah Dasar Fakultas Ilmu Pendidikan Universitas Negeri Semarang.

Siswanto, D. 2020. Anak di Persimpangan Perceraian (Menilik Pol Asuh Anak Korban Perceraian). Surabaya: Airlangga University Press. 